\title{
O Clube de Software da SPQ (2 $2^{\mathrm{a}}$ parte $)$
}

\author{
J O Ã O P A U O L E A L *
}

No Seguimento da listagem publicada anteriormente nesta revista ${ }^{1}$, apresenta-se aqui o software que a SPQ adquiriu ou the foi oferecido desde então, e que se encontra à disposição dos sócios para consulta na sede da SPQ. Tal como na primeira parte desta listagem procurou-se classificar os programas quanto à sua qualidade (1 a 5), adequação aos vários níveis de ensino (A, B e C) e recursos de inglês

necessários (I, II e III, pois muitos dos programas continuam a ser em inglês). Pode-se reparar que os programas apresentados na primeira parte eram todos para o sistema operativo MS-DOS, ao passo que muitos dos agora apresentados necessitam um ambiente Windows para correrem, daí um quarto índice na classificação que especifica se o programa corre sobre MS-DOS (D) ou se necessita ambiente Windows(W). É de notar também que a qualidade média dos programas agora apresentados é superior à dos programas apresentados na $1^{\mathrm{a}}$ parte, 0 que reflete uma procura de qualidade na aquisição do software. Por este facto, e também por se sentir que a brevíssima explicação dada sobre os programas anteriormente era insuficiente, o comentário a cada um dos programas vai ser um pouco mais extenso.

\section{Chemical Education Software}

Barreira Quântica (3,C,I,D) Pequeno programa de demonstração que apresenta a noção de barreira quântica. Podem alterar-se vários pa- râmetros como a altura e a largura da barreira ou a energia e intensidade do feixe incidente e verificar como esses parâmetros afectam o número e a energia das partículas que conseguem atravessar a barreira.

\section{Difracção de Cristal Único} (3,C,I,D) - Programa de demonstração que representa esquemáticamente uma experiência de difracção mostrando como vão aparecendo as reflexões numa película fotográfica à medida que o cristal roda. É agradável à vista, mas não permite uma grande interactividade e a versão existente está limitada a um cristal com uma célula cúbica.

\section{Laboratório de Cinética} (4/5,B,II,D) - Programa muito bom começa com a escolha das condições reaccionais e do tipo de reacção e vai por aí fora: amostragem para análise das concentrações dos reagentes e produtos, representações gráficas, cálculo das ordens de reaç̧ão em relação aos vários reagentes, e finalmente constantes de velocidade e energias de activação. Tudo apresentado de maneira simples mas bem estruturada, e possuindo um auxiliar razoável para os casos de dúvidas.

SIR I (Simulations and Interactive Resources) (5, B,II,D) - O nome não é muito esclarecedor, mas é um muito bom programa. Apresenta uma série de "acetatos interactivos" sobre sete temas que vão desde cinética, a reacções ácido-base e a termoquímica, muitos deles com vários sub-temas num total de doze. Para quem tiver um "data-sheet" é um auxiliar precioso para apresentar estas matérias numa aula. Saiu recentemente uma nova versão (c/ 19 sub-temas) da qual se fará uma análise mais detalhada nas páginas desta revista.

WinDNMR (4,C,I,W) - O D do título refere-se a dinâmico, pois este simulador de espectros de Ressonância Magnética Nuclear(RMN) permite alterar dinamicamente os parâmetros de modo a demonstrar conceitos importantes neste tipo de espectroscopia. Quer perceber, ou explicar, porque é que as intensidades dos multipletos vem distorcida ou porque é que núcleos equivalentes não apresentam acoplamento entre si? Este programa tem a resposta.

HPLC for Windows (4,C,I,W) - É uma versão melhorada dum programa da mesma editora para DOS [1] mas com algumas novidades e a facilidade de ser para windows. Possui seis módulos que cobrem desde a preparação da amostra, à selecção do solvente e da coluna, ao controle do painel do instrumento ou ao sistema de aquisição de dados por computador. Muito pedagógico e um bom auxiliar a praticar antes do primeiro contacto com um aparelho de HPLC.

Molecular Dynamics Simulator $(4, \mathrm{~B} / \mathrm{C}, \mathrm{I}, \mathrm{W})$ - Proporciona uma visualização do movimento molecular num sólido, líquido ou gás (dependendo das condições de temperatura e pressão escolhidas). Bastante bom para se compreender quais os parâmetros que determinam a fase de uma substância. Pena é que as 32 moléculas consideradas não sejam em número suficiente para que se possa simular um sistema bi-fásico. 
Equilibrium Calculator (4, B, I, W) - Permite calcular as concentrações no equilíbrio para uma reacção qualquer com até 5 produtos e 5 reagentes distintos. Necessita que lhe sejam fornecidos os coeficientes estequiométricos, as concentrações iniciais e a constante de equilíbrio. Simples mas muito efectivo, dá sempre jeito.

Periodic Table CD (4,A/B,I,W) - Como é bom de ver, além do ambiente windows requer um leitor de CD-ROM preferencialmente de quádrupla velocidade. Mas vale a pena. Alguma vez pensou fazer a reacção de potássio com a água ou a ignição de um balão cheio de hidrogénio com um bico de Bunsen e desistiu, por razões de segurança ou de falta de meios? Pode agora ver estas e tantas outras reacções em seguências animadas sem perigo para si ou para os alunos numa sala de aulas. Com a vantagem de poder repetir a experiência as vezes que quiser ou analisála em câmara lenta para ver bem os detalhes.

\section{SoftCiências}

Jogos Químicos (4,A/B,-,D) Programa que nos dá acesso a dois jogos que na sua simplicidade constituem uma ferramenta importante na aprendizagem da química e do método ciêntifico em geral. O jogo das substâncias em que o computador escolhe uma de uma lista de substâncias (sem nos dizer qual) e uma lista de propriedades (estado físico, solubilidade, etc.) sobre as quais podemos obter respostas de sim ou não. Pretende-se adivinhar qual a substância escolhida utilizando o menor número de perguntas. $\mathrm{O}$ jogo das adivinhas em que tudo gira em redor de temas de química. Mas é bom não nos enganarmos ou aparece um tubo de ensaio muito zangado.

Le Chat (4, B, -,D) - De Le Chatelier. Este programa foi analisado em detalhe na ref. 2.

Energia (3, A,-,D) - Jogo em que nós vamos gerir os destinos do planeta nas próximas 15 décadas (acabamos o jogo já velhinhos) escolhendo que tipo de fontes (petróleo, gás natural, nuclear, energias alternativas) utilizamos para produzir a energia para o nosso mundo. Mas atenção com o crescimento populacional e a poluição. Bom para criar a consciência de que os recursos não são inesgotáveis e de que se necessita de uma gestão mais racional dos mesmos.

Millikan (4,B,-,D) - Trata-se da famosa experiência da gota de óleo efectuada por Millikan. Grafismo engraçado, boas ajudas ao longo do programa (experiência) e o facto de ser em português contribuem para a qualidade do programa. Uma maneira interessante de mostrar que a carga do electrão não é apenas mais um valor nos livros de texto mas que corresponde a uma realidade física bem determinada e que a sua determinação é o corolário de muito trabalho de muitos cientistas até chegar a Millikan.

\section{Oxford University Press}

DTMM (DeskTop Molecular Modeller) (5,B/C,I,D) - Se pretende desenhar moléculas de um modo simples, rodá-las, vê-las de todos os ângulos, com ou sem o raio de van der
Waals, projectá-las num plano ou ver uma conformação alinhada por uma ligação este programa pode ser uma solução. Muito intuitivo, possui de origem cerca de uma vintena de moléculas e dezena de fragmentos em memória. Mas podem adquirir-se as bibliotecas de Orgânica, Inorgânica e Bioquímica que elevam o número de estruturas em memória para lá das duas centenas. Conhece a estrutura da hélice do $\mathrm{ADN}$ ? Não, então vá ver, está lá...

\section{Synopsis Scientific Systems Ltd.1}

Accord for Microsoft Excel (v.2.0) (4,-,I,W) - Trata-se de um programa que se adiciona ao Excel (folha de cálculo) de modo que este passe a reconhecer fórmulas químicas (estruturalmente desenhadas). Permite que se pesquise por estrutura ou subestrutura existindo ainda algumas facilidades como o cálculo da fórmula bruta, da massa molar, etc. É compatível com vários programas de desenho de estruturas (ChemDraw, ChemWindow).

\section{Accord for Microsoft Access}

(v.1.10) (4,-,I,W) - Trata-se de um programa que se adiciona ao Access (base de dados) de modo que este passe a reconhecer fórmulas químicas (estruturalmente desenhadas). Apresenta o mesmo tipo de facilidades que o seu homónimo para o Excel.

\footnotetext{
* Dep. Química, ITN (ex-ICEN-INETI), Sacavém.

1. Química 52, (1994) 60.

2. Química 54, (1994) 92.
}

I Uma análise detalhada dos dois programas apresentados será feita brevemente nesta revista. 